\title{
Controlled-release Fertilizer in the Production and Quality of Acacia mangium Seedlings
}

\author{
Lazara Daniela Dias Silva ${ }^{1}$ (D), Ana Paula Leite Lima ${ }^{1}$ (D), \\ Sebastião Ferreira de Lima ${ }^{1}$ (D), Rogério Costa Silva ${ }^{1}$ (D), \\ Geislaine Ferreira Paniago ${ }^{1}$
}

${ }^{1}$ Universidade Federal de Mato Grosso do Sul - UFMS, Chapadão do Sul/MS, Brasil

\begin{abstract}
In order to evaluate the use of controlled-release fertilizer in the production and quality of Acacia mangium seedlings, this experiment was conducted in randomized blocks, and treatments consisted of five levels $\left(0,2.5,5.0,7.5\right.$ and $10.0 \mathrm{~kg} \mathrm{~m}^{-3}$ of substrate) of Osmocote Plus ${ }^{\circledR}$ in six replicates. After 130 days of sowing, the production and quality variables of Acacia seedlings were analyzed. All production and quality variables, height/shoot ratio (HSH) and Dickson quality index (DQI) were influenced by the fertilizer doses. The greatest mean values of stem diameter, total height, shoot dry mass, root dry mass, the best HSH and the highest DQI, were obtained for doses ranging from 7.1 to $7.8 \mathrm{~kg} \mathrm{~m}^{-3}$ of substrate. The largest leaf area was obtained using a dose of $9.3 \mathrm{~kg} \mathrm{~m}^{-3}$ of substrate.
\end{abstract}

Keywords: fertilization, forest species, nursery. 


\section{INTRODUCTION}

For the Brazilian economy, the increasing consumption of wood from planted forests represents a productive potential that mitigates the pressure exerted on native forests. Thus, exotic species of rapid growth, high production capacity and multiple uses have become viable alternatives in the country's forest sector (IBA, 2016).

Brazilian forestry is currently consolidated by extensive research and investments on Eucalyptus and Pinus species (Somavilla et al., 2014). However, other exotic species of great productive ability are limited to the little available information regarding the production of seedlings and some silvicultural aspects. This lack of information is because of its recent introduction to the country, in comparison to the aforementioned species, such as the Acacia mangium species (Tonini et al., 2010).

Brazil has approximately 160 thousand hectares of area planted with the Acacia genus (IBA, 2016). Of these, more than 25 thousand hectares are planted with A. mangium in savanna areas of Roraima, with a high prospective for commercially expanding its plantations (Barros et al., 2009). However, investments in genetic improvement, nutritional research and improvement in the productive system are necessary so that the formed forest stands express the true productive capacity of the species and the site.

A. mangium belongs to the Fabaceae family and is an exotic species native from Australia that has adapted to Brazilian soil and climate conditions. It presents relatively rapid growth, low nutritional requirements, tolerance to acid and compacted soils, as well as symbiotic interaction with nitrogen-fixing bacteria and arbuscular mycorrhizal fungi (Rossi et al., 2003; Tonini et al., 2010). Under optimal management conditions, it can present an average annual growth of $45 \mathrm{~m}^{3} \mathrm{ha}^{-1}$ year ${ }^{-1}$, similar to that of eucalyptus (Veiga et al., 2000 ), reason why it has been considered a promising species for the Brazilian forestry sector, and favoring its expansion to biomes such as the Brazilian Cerrado.

In order to achieve high productivity, attention must be paid to various silvicultural aspects that cover the use of techniques that favor producing good quality seedlings (Ceconi et al., 2007; Brondani et al., 2008). Therefore, allied to a substrate that presents adequate physical and chemical properties for seedlings formation, soil enrichment with controlled-release fertilizer in adequate doses can reduce the formation time of the seedlings and losses by leaching and volatilization, favoring the use of available nutrients and allowing greater seedling development and quality in the nursery, and consequently reducing the mortality rate of the plants under establishment in the field (Simões et al., 2012; Stüpp et al., 2015; Menegatti et al., 2017).

The use of controlled-release fertilizers is a nutritional contribution technology for forest species (Rossa et al., 2015a). These fertilizers include soluble compounds in their interior (NPK and some micronutrients) surrounded by a semipermeable membrane that, depending on the temperature and humidity of the substrate, dilates and contracts, which causes the release of nutrients to be controlled and made available gradually, thereby maintaining constant levels of the essential elements for the seedlings throughout the growth period (Bennett, 1996; José et al., 2009).

Applying controlled-release fertilizer in Eucalyptus grandis seedling production provided better quality standards of seedlings compared to those obtained with the use of conventional fertilizer (Rossa et al., 2015b). For the seedling formation of Anadenanthera peregrina and Schinus terebinthifolius, Rossa et al. (2015a) verified that application of the controlled-release fertilizer provided significant gains in seedling growth when compared to the unfertilized plants. Somavilla et al. (2014) verified that the use of the same fertilizer provided an increase in all evaluated parameters for the production and quality of Toona ciliata seedlings. On the other hand, Stüpp et al. (2015) observed that the doses of controlled-release fertilizer influenced the initial growth of Mimosa scabrella seedlings; however, its positive effect was verified only up to a certain dose, and further on from this dose it became negative, verifying that excess of this fertilizer can hinder seedling growth.

Thus, the present study had the objective of evaluating the application of controlled-release fertilizer on the production and quality of Acacia mangium seedlings.

\section{MATERIAL AND METHODS}

The experiment was installed in September 2014 at the Federal University of Mato Grosso do Sul (UFMS) on the Campus of Chapadão do Sul, MS, Brazil, in a 
greenhouse with lateral sombrite coating (50\%) and humidity controlled by a micro sprinkler irrigation system.

The experimental design was in randomized blocks with five treatments of controlled-release fertilizer (Osmocote Plus $^{\circledR}$ (15-09-12 + micro) with release of 3 to 4 months), at doses $0,2.5,5.0,7.5$ and $10 \mathrm{~kg} \mathrm{~m}^{-3}$ of substrate with six replicates. Each parcel consisted of 18 polyethylene bags with $8 \times 12 \mathrm{~cm}$ dimension and volume $550 \mathrm{~cm}^{3}$ of $A$. mangium seedlings per container. The nutrient concentrations found in the Osmocote are: $15 \%$ of $\mathrm{N}, 9 \%$ of $\mathrm{P}_{2} \mathrm{O}_{5}, 12 \%$ of $\mathrm{K}_{2} \mathrm{O}, 1.3 \%$ of $\mathrm{Mg}$, $5.9 \%$ of $\mathrm{S}, 0.02 \%$ of $\mathrm{B}, 0.05 \%$ of $\mathrm{Cu}, 0.46 \%$ of $\mathrm{Fe}, 0.06 \%$ of $\mathrm{Mn}, 0.02 \%$ of Mo and $0.05 \%$ of $\mathrm{Zn}$.

A mixture of soil (Typic Hapludult soil), sand and cow manure was used as substrate for seedling formation in the volumetric ratio of 2:1:1. Mixing the substrate components as well as homogenizing the fertilizer doses into the substrate was carried out using a concrete mixer for a period of approximately 10 minutes.

Prior to the sowing, A. mangium seeds were disinfested with $3 \%$ sodium hypochlorite for two minutes. Next, dormancy was interrupted using hot water immersion $\left(100^{\circ} \mathrm{C}\right)$ for one minute. Three seeds were used per container for sowing, and thinning was carried out after the seedlings reached 3 to $4 \mathrm{~cm}$ in height, leaving only the most vigorous and central seedling in each container.

After 130 days of sowing, three medium height seedlings were selected per plot, in which the stem diameter (StD) and the total height (TH) were measured using a digital caliper and a graduated ruler, respectively. After evaluation in the nursery, the selected seedlings were then taken to the Forest Engineering Laboratory of the UFMS and sectioned into roots and shoots per sample. The shoot part was separated into stem and leaves, and the leaves were used to determine the leaf area of each tree/sample using a CI-203CA Bioscience leaf area meter. The roots were washed in running water over a sieve and subsequently placed to dry together with the shoot in a forced circulation oven at $65^{\circ} \mathrm{C}$ for 48 hours in order to determine the root (RDW) and shoot dry weight (SDW) per seedling. The seedlings' quality was obtained according to: height/diameter ratio (HDR), height/shoot ratio (HSR), shoot/root ratio (SRR), and the Dickson quality index (DQI) (Dickson et al., 1960).

Data were submitted to analysis of variance and the $\mathrm{F}$ test at $5 \%$ probability. In cases of significant differences between treatments, polynomial regression analysis was performed where the equations were defined by the $\mathrm{F}$ test when they reached a significance level of $5 \%$ probability.

\section{RESULTS AND DISCUSSION}

All seedling production variables analyzed were influenced by the Osmocote Plus ${ }^{\circledR}$ dose tested. Increasing doses of controlled-release fertilizer provided significant increases in stem diameter, total height, leaf area, root dry weight and shoot dry weight compared to the unfertilized A. mangium seedlings. However, a reduction in the seedling gain was observed after a specific dose, which varied according to the evaluated parameters.

The best diameter development $(2.77 \mathrm{~mm})$ was achieved with the dose of $7.77 \mathrm{~kg} \mathrm{~m}^{-3}$ of substrate, while the smallest diameter $(1.87 \mathrm{~mm})$ was observed for unfertilized seedlings (Figure 1a). Thus, the application of this dose corresponded to a $48 \%$ increase in seedling diameter. A similar result was observed by Somavilla et al. (2014) using the same fertilizer and formulation (15-09-12) for Toona ciliata seedlings, in which the best dose for diameter growth was $7.50 \mathrm{~kg} \mathrm{~m}^{-3}$ of substrate, while the smallest diameters were found for unfertilized seedlings. Diameter is the most relevant parameter among the evaluated variables to indicate seedling quality, since it presents a high degree of relationship with DQI (Binotto, 2007).

The height development of $A$. mangium seedlings had a similar behavior to that of the diameter variable, with the best response being found for the dose of $7.06 \mathrm{~kg} \mathrm{~m}^{-3}$ of substrate $(30.41 \mathrm{~cm})$, and with the smallest height $(20.55 \mathrm{~cm})$ being observed for the unfertilized seedlings (Figure 1b), representing an increase of approximately $48 \%$ in height. These results are similar to the observation made by Rossa et al. (2015a) on the significant gains in seedling height compared to unfertilized plants. In another study comparing conventional fertilization with controlled-release fertilizer, Rossa et al. (2015b) found that all the seedlings of Eucalyptus grandis that received doses of controlled-release fertilizer reached higher heights than those that received conventional 

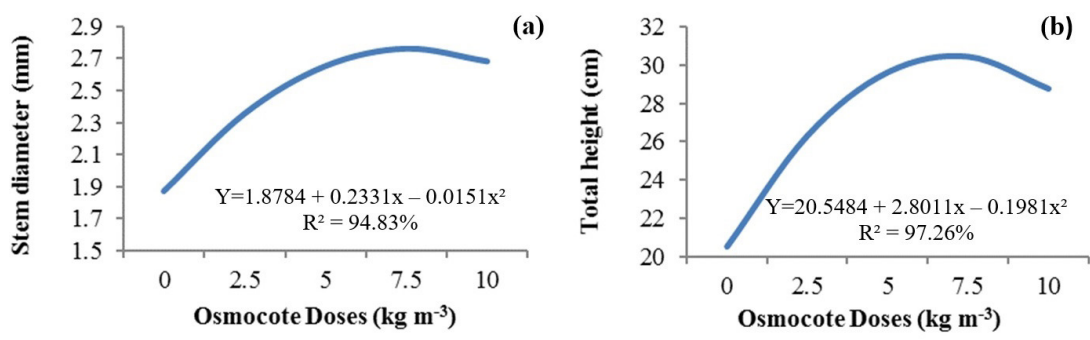

(c)

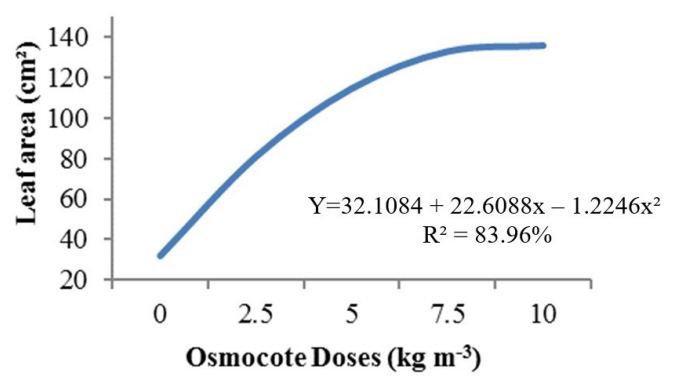

Figure 1. Stem diameter $(\mathrm{mm})(\mathrm{a})$, total height $(\mathrm{b})$, and leaf area $\left(\mathrm{cm}^{2}\right)$ (c) of Acacia mangium regarding the application of controlled-release fertilizer doses.

fertilization, emphasizing the importance of a continuous availability of nutrients during the seedling formation period. This reinforces the observation from Zhang (2007), who emphasizes the use of controlled-release fertilizer for optimizing the usage of the available nutrients through the possible reduction of leaching losses and volatilization, thereby favoring plant growth.

Following the same behavior, the leaf area $\left(\mathrm{cm}^{2}\right)$ per A. mangium seedling increased with the application of increasing doses of Osmocote Plus ${ }^{\circledR}$ up to the dose of $9.23 \mathrm{~kg} \mathrm{~m}^{-3}$ of substrate $\left(135.73 \mathrm{~cm}^{2}\right.$ ) (Figure 1c). Therefore, a greater leaf area value is related to a greater photosynthetic area, propitiating an increase in photoassimilate production for the seedlings, having great importance for the formation of good quality seedlings and for its vigorous establishment in the field (Santos et al., 2014).

It is observed that among the production variables, leaf area $\left(\mathrm{cm}^{2}\right)$ presented better development in response to the higher level of fertilization $9.23 \mathrm{~kg} \mathrm{~m}^{-3}$ of substrate, differing from the other results obtained ranging from 7.06 to $7.77 \mathrm{~kg} \mathrm{~m}^{-3}$ of substrate. According to Elli et al. (2013), the morphological and physiological characteristics of each organ of the seedlings may comprise a different fertilization level for each one.
For shoot (SDW) and root dry weight (RDW), the use of increasing doses of Osmocote Plus ${ }^{\circledR}$ provided increases in the fertilized seedlings' development, reaching the maximum dry mass values of $1.50 \mathrm{~g}$ (SDW) and $0.40 \mathrm{~g}$ (RDW) with the doses of 7.62 and $7.54 \mathrm{~kg} \mathrm{~m}^{-3}$ of substrate, respectively (Figures 2a and 2b). Somavilla et al. (2014) observed the same behavior for Toona ciliata seedlings related to the controlled-release fertilizer dose for this species, where the highest values were obtained using $8.8 \mathrm{~kg} \mathrm{~m}^{-3}$ of substrate for shoot and root dry weight production at 150 days after fertilization.

By analyzing the quality indices of seedlings, we found that doses of 7.52 and $7.78 \mathrm{~kg} \mathrm{~m}^{-3}$ of substrate provided the best results for the HSR and DQI variables, respectively (Figures $3 a$ and $3 b$ ). For forest species, Hunt (1990) established that seedling quality indexes (HSR and DQI) should be less than 10 and greater than 0.2 , so that the seedlings present good quality and high survival after planting, respectively. However, Binotto (2007) points out that it is necessary to establish tests for DQI calibration for each forest species of interest. Moreover, the same author reports that diameter has a high relation with DQI; thus, doses that allow greater development 
in stem diameter of the seedlings will favor better seedling quality. Although the highest DQI value was less than 0.20 in the present study, the dose that provided this value $\left(7.78 \mathrm{~kg} \mathrm{~m}^{-3}\right.$ of substrate) was the same found for the best diameter development (7.77 $\mathrm{kg} \mathrm{m}^{-3}$ of substrate), thus indicating a good quality standard.

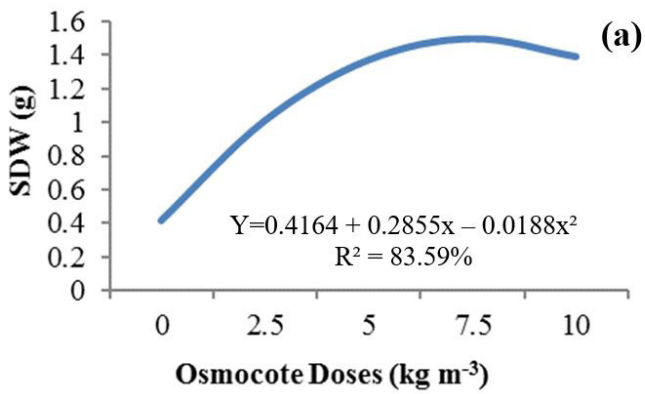

Figure 2. Shoot dry weight (a) and root dry weight (b) of Acacia mangium regarding the application of controlled-release fertilizer doses.
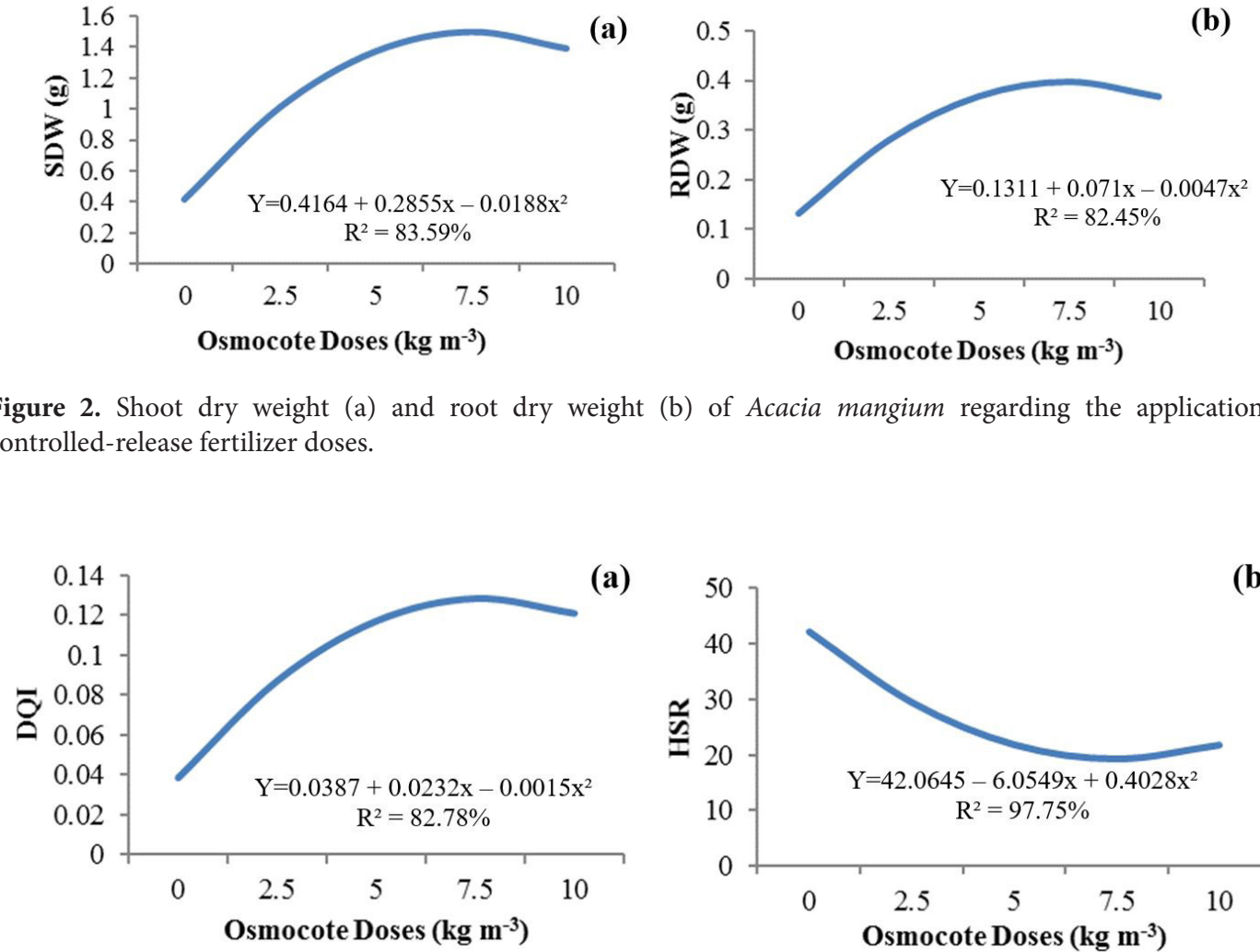

Figure 3. Dickson Quality Index (DQI) (a) and height/shoot dry weight ratio (HSR) (b) of Acacia mangium regarding the application of controlled- release fertilizer doses.
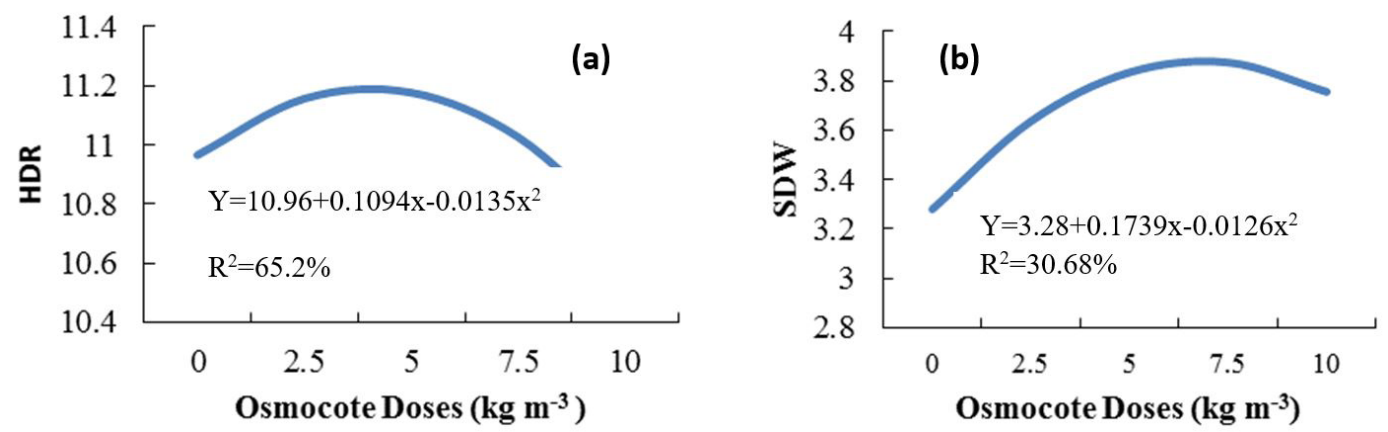

Figure 4. Height/diameter ratio (a) and shoot dry weight ratio (b) of Acacia mangium regarding the application of controlled-release fertilizer doses. 


\section{CONCLUSION}

All evaluated production parameters responded positively to the use of the Osmocote Plus ${ }^{\circledR}$ fertilizer. The best results obtained varied according to the parameters in which the highest mean values for height, stem diameter, shoot dry weight and root dry weight were observed in the dose range from 7.1 to $7.8 \mathrm{~kg} \mathrm{~m}^{-3}$ of substrate, and the highest leaf area was reached with a $9.3 \mathrm{~kg} \mathrm{~m}^{-3}$ dose of Osmocote Plus ${ }^{\circledR}$ substrate.

HSR and DQI were positively influenced by the application of Osmocote Plus ${ }^{\circledR}$, in which doses of 7.52 and $7.78 \mathrm{~kg} \mathrm{~m}^{-3}$ provided the best results, respectively.

\section{SUBMISSION STATUS}

Received: 21 feb., 2017

Accepted: 26 oct., 2017

\section{CORRESPONDENCE TO}

\section{Sebastião Ferreira de Lima}

Universidade Federal de Mato Grosso do Sul UFMS, Campus de Chapadão do Sul, Rod. MS 306, Km 105, CP 112, CEP 79560-000, Chapadão do Sul, MS, Brasil

e-mail: sebastiao.lima@ufms.br

\section{REFERENCES}

Barros LS, Vale JF Jr, Schaefer CEGR, Mourão M Jr. Perdas de solo e água em plantio de Acacia mangium Wild e savana em Roraima, Norte da Amazônia. Revista Brasileira de Ciência do Solo 2009; 33(2): 447-454. http:// dx.doi.org/10.1590/S0100-06832009000200022.

Bennett E. Slow-release fertilizers. Virginia Gardener Newsletter [online]. 1996; 11(4) [cited 2016 Aug 14]. Available from: www.ext.vt.edu/departments/envirohort/ articles/misc/slowrels.html

Binotto AF. Relação entre variáveis de crescimento e o índice de qualidade de Dickson em mudas de Eucalyptus grandis W. Hill ex Maid e Pinus elliottii var. elliottii [dissertação]. Santa Maria: Universidade Federal de Santa Maria; 2007.

Brondani GE, Silva AJC, Rego SS, Grisi FA, Nogueira AC, Wendling I et al. Fertilização de liberação controlada no crescimento inicial de angico-branco. Scientia Agraria 2008; 9(2): 167-176. http://dx.doi.org/10.5380/rsa.v9i2.10965.

Ceconi DE, Poletto I, Lovato T, Muniz MFB. Exigência nutricional de mudas de erva-mate (Ilex paraguariensis
A. St.-Hil.) à adubação fosfatada. Revista Ciência Florestal 2007; 17(1): 25-32. http://dx.doi.org/10.5902/198050981932.

Dickson A, Leaf AL, Hosner JF. Quality appraisal of white spruce and white pine seedling stock in nurseries. Forestry Chronicle 1960; 36(1): 10-13. http://dx.doi.org/10.5558/ tfc36010-1.

Dutra TR, Grazziotti PH, Santana RC, Massad MD. Desenvolvimento inicial de mudas de copaíba sob diferentes níveis de sombreamento e substratos. Revista Ciência Agronômica 2012; 43(2): 321-329. http://dx.doi. org/10.1590/S1806-66902012000200015.

Elli EF, Caron BO, Monteiro GC, Pavan MA, Pedrassani $\mathrm{M}$, Cantarelli EB et al. Osmocote ${ }^{\circledR}$ no desenvolvimento e comportamento fisiológico de mudas de pitangueira. Comunicata Scientiae: Science Wiht Qualit 2013; 4(4): 377-384.

Hunt GA. Effect of styroblock design and cooper treatment on morphology of conifer seedlings. In: Target Seedling Symposium, Meeting of the Western Forest Nursery Associations; 1990; Roseburg, Fort Collins. Roseburg: Departament of Agriculture, Forest Service; 1990. p. 218-222.

Indústria Brasileira de Árvores - IBA. Relatório anual: ano base 2015. Brasília; 2016.

José AC, Davide AC, Oliveira SL. Efeito do volume do tubete, tipo e dosagem de adubo na produção de mudas de aroeira (Schinus terebinthifolia Raddi). Agrarian 2009; 2(3): 73-86.

Menegatti RD, Navroski MC, Guallo K, Fior CS, Souza AG, Possenti JC. Formação de mudas de guatambu em substrato com hidrogel e fertilizante de liberação controlada. Revista Espacios 2017; 38(22): 35-47.

Rossa UB, Angelo AC, Westphalen DJ, Oliveira FEM, Silva FF, Araujo JC. Fertilizante de liberação lenta no desenvolvimento de mudas de Anadenanthera peregrina (1.) Speg. (angico-vermelho) e Schinus terebinthifolius Raddi (aroeira-vermelha). Ciência Florestal 2015a; 25(4): 841-852. http://dx.doi.org/10.5902/1980509820582.

Rossa UB, Angelo AC, Bognola IA, Westphalen DJ, Milani JEF. Fertilização de liberação lenta no desenvolvimento de mudas de Eucalyptus grandis. Floresta 2015b; 45(1): 85-96. http://dx.doi.org/10.5380/rf.v45i1.31224.

Rossi LMB, Azevedo CP, Souza CR. Acacia mangium. Manaus: Embrapa Amazônia Ocidental; 2003. (Embrapa Amazônia Ocidental Documentos; no. 28).

Santos CC, Motta IS, Carneiro LF, Santos MCS, Padovan MP, Mariani A. Produção agroecológica de mudas de maracujá em substratos a base de húmus de minhoca e casca de arroz carbonizada. Cadernos de Agroecologia 2014; 9(4): 1-10.

Simões D, Silva RBG, Silva MR. Composição do substrato sobre o desenvolvimento, qualidade e custo de produção de mudas de Eucalyptus grandis Hill ex. Maiden x Eucalyptus urophylla s. T. Blake. Ciência Florestal 2012; 22(1): 91-100. http://dx.doi.org/10.5902/198050985082. 
Somavilla A, Cantarelli EB, Mariano LG, Ortigara C, Luz FB. Avaliações morfológicas de mudas de Cedro australiano submetidas a diferentes doses do fertilizante osmocote plus ${ }^{\circledR}$. Comunicata Scientiae Science Wiht Qualit 2014; 5(4): 493-498.

Stüpp AM, Navroski MC, Felippe D, Kniess DDC, Amancio JC, Silva MA et al. Crescimento de mudas de Mimosa scabrella Benth em função de diferentes tamanhos de recipientes e doses de fertilizante. Ecologia e Nutrição Florestal 2015; 3(2): 40-47.
Tonini H, Halfeld-Vieira BA, Silva SJR. Acacia mangium: características e seu cultivo em Roraima. Brasília: Embrapa Informação Tecnológica, Embrapa Roraima; 2010.

Veiga RAA, Carvalho CM, Brasil MAM. Determinação de equações de volume para árvores de Acacia mangium. Cerne 2000; 6(1): 103-107.

Zhang M. Effect of coated controlled-release fertilizer on yield increase and environmental significance. Ecology \& Environment 2007. In press. 